\title{
Examining the Concept of the 'Other' According to Edward W. Said
}

\author{
Boubaker Mohrem \\ Research Scholar \\ University of Jordan \\ Amman, Jordan \\ boubakermohrem@gmail.com
}

\begin{abstract}
After the World War II, the world remarks many changes in every aspect including culture, society, literature and so on. Writers around the world wrote about the effect of colonizer/colonized relationship. Edward Said is one of the pillars who deals with such discourse. Said believes that the legacy of the colonizer still exists in terms of civil wars, corruption and labor exploitation. In other word, Said means that the West creates a wrong image about the Orient and considers it as the "Other" in contrast to the ideal West. Said was the one who deconstructs the western's thinking about the East. So his books:

Orientalism (1978), The Question of Palestine (1979) and Covering Islam (1981) are appropriate to examine the idea of the 'Other' and to show how Said decipher the western wrong image about the East. Thus, this paper will emphasis on the concept of the Other according to Said.
\end{abstract}

Keyword: The Other, The East, The West, Postcolonial. 
This paper explores the theory of post colonialism, which is a literary theory that deals with different disciplines, which have a relation with the impact of the colonizer such as European countries on the colonized ones like African countries and so forth. In a sense, this paper examines the representation of the Other in postcolonial perspective. Ashcroft in the Empire Writes Back (1989) says "We use the term 'post-colonial', however, to cover all the culture affected by the imperial process from the moment of colonization to the present day" (Ashcroft, 1). The impact of the colonizer touches many aspects in the colonized areas, such as the culture, race and life of people in general, especially during the nineteenth and twentieth centuries. Edward Wadie Said, a Palestinian critic. In his famous work Orientalism 1978, he discusses the old and new study of Eastern societies' culture, language and people by Western thinkers. Said's concept of the "Other" a prejudiced image on the Orient that has been created and perpetuated through the Western discourse. In 'The Question of Palestine 1979 has been besides Covering Islam 1981 which Muslims have been identified as the Other. Postcolonial literary theory from Edward Said's viewpoint discusses the wrong image created to represent the East. Therefore, Said believes that there are ways like texts tried to make the East or "other" seem undeveloped and without civilization in the eyes of the West. Orientalism 1978 is one of the famous works by Edward Said. At first, Said defines Orientalism as "A style of thought based upon an ontological and epistemological distinction made between "the Orient" and (most of the time)"the Occident" (Lutfi, 2).Edward Said could be cited more than one time when talking about the Other beside Orientalism 1978. Beside his Orientalism there are two books which tackles the concept of the Other or the Orient. The Question of Palestine 1979 and Covering Islam 1981, each time the Other considers as the Orient, but in Covering Islam the Other in that book were the Muslims. Back to Orientalism, Said explains as he mentions the writers as an umbrella, this umbrella covers the imperial administration, poets, novelists, political theorists, economists and philosophers who have accepted the difference between the 
East and West as a point to start their theories and assumptions concerning the Orient (Said, 2).

Earlier, Said emphasizes on the power of the Orient and the Orient is not fallacy. In this way, he wants to say that the issue is related to power and hegemony:

'Ideas, cultures, and histories cannot seriously be understood or studied without their force, or more precisely their configurations of power, also being studied. To believe that Orient was created_or, as I call it, 'Orientalized' and to believe that such things happen simply as a necessity of the imagination is to be disingenuous.... The Orient was Orientalized not only because it was discovered to be Oriental in all those ways considered commonplace by an average nineteenth century European, but also because it could be _that is submitted to being made Oriental' $(5,6)$.

On the other hand, Said sees that the results of colonialization still exist in different shapes of civil wars, corruption and coups. He also argues that the culture, history and language have been ignored by their original countries and they have been replaced by the colonial's values and culture because of the power of the colonizer. Additionally, this is not only the case of the East compared to the West, but it applies to other continents such as the case of Africa. Moreover, considers the other writers from the other continents and their texts as the Orient or the "Other" from Said's perspective in contiguity with the West. Again, Said's ideas and concepts in Orientalism 1978 depicted the oppression that is practiced against the colonized countries. He portrays how the West benefits from and sees the Orient. For Edward Said:

"European history of interest in the East, particular parts of the Orient like Egypt, Syria and Arabia cannot be discussed without also studying Europe's involvement in the more distant parts, of which Persia and India are the most important; a notable case in point is the connection between Egypt and India so far as eighteenth and nineteenth-century Britain was concerned" (17). 
Therefore, Said comes again with another definition of Orientalism by saying that: "it is not political subject, nor it is text about the Orient, nor it is nefarious Western imperialist to hold down the Oriental world, it is a distribution of geopolitical awareness into aesthetic scholarly, economic, sociological, historical and philological texts” (Said, 12). Said still argues that ideas written about the East are wrong. . In order to conquer and defeat the East, the Western world labeled the Orient, as the "Other". This idea can be summarized in the notion of narrative, the West has the power of narrative and the power of knowledge that is why it is granted the status of a center. Said says "The relationship between Occident and Orient is a relationship of power, of domination, of varying degrees of a complex hegemony" (Said, 5).

Moreover, Said mentions that the world is built up of the stereotypes by which the Orient is viewed (Said, 26). In his point of view, during the nineteenth century and after the World War Two, media played an important role to depict "the mysterious Orient" (Said, 26). In a word, Said assumes that Orientalists' intention to wipe the Oriental world as a human being because of academic and intellectual matters. He also adds, Orientalism persuades Said himself and his colleagues to say that society and literary culture can be understandable only if they are studied together (Said, 27).

In Orientalism, Said claims that literary texts are tools used by the colonizer and those texts misrepresent the image of the Orient. In this sense, Said goes back to an earlier time when talking about the Athenian play of Aeschylus's the Persians and The Bacchane of Euripides. Aeschylus depicted the sensation of the risk when the Persians heard that their armies were destroyed by the Greek. Said demonstrates using the two works from an earlier time how Asia has been depicted as the "Other," a world beyond the seas or Asia speaks out of European imagination (Said, 56). Said speaks in his book about other writers in reference with their works. For instance, Renan's and Sacy's works have been dealt as a source in the studies of the Orient. Renan who studies the philology and language sees that "European prose points out 
defects, virtues, barbarisms and shortcomings in the language, the people and the civilization"(Said, 142). In a review untitled Western Media and Islam, Said's work of Covering Islam testify the view of American media and scholars while presenting such "caricature" of the Islam and to all the Arab world in a way to show it to the US public(Reilly, 2). As a part of this book seen as familiar to the Orientalism 1977, Said's idea is that to check the historical relationship between the Islam and the West, and he concludes saying that the West during its age has discussed Islam "outside" the scope (Reilly, 3). Also, Said puts his attention to the US media covering Iranian Revolution. Besides in his chapter of Knowledge and Power, Said wonder although the fault of the media and academic scholars still exist. Further, he sees that there is close relationship between the knowledge and power in the United States Middle Eastern Studies foundation. However, he believes that there is a close circle in that idea since many of experts even from the Muslim world who belong to that foundation as it is explained: "such that a young scholar holding an unorthodox point of view which challenges the accepted wisdom on the Middle East is unlikely to receive a hearing, or even find."(Reilly, 4). In the end Said composes "the time has come for these ties to be severed completely "Said sketches that there are such association and people in the West seeks "antithetical knowledge" that defies the Orientalist values (Reilly, 4).

In fact, Said's work of Orientalism has been a subject of much debate in the eyes of critics. Orientalism 1977 receives critiques especially from Marxist writers like the Indian writer Aijaz Ahmed in his book In theory: Nations, Classes, Literatures 1992, and so forth. In contrary, some scholars see that it is paradoxical that Said offenses the West in the same time he is benefiting from the Occident and they see Said as being Palestinian just as a veil to consider himself the martyr in which he have never been there. Edward Said is a distinctive voice in the academia; his writings about the orient have defined the contours of the postcolonial approach. In his Orientalism, Said argues that the Western writings about the 
Orient is based on imagination and it is a mere mythology to help the West spread authority over its symmetrical other; the Orient.

To some extent, it is obvious that in order to read any piece of literature with critical insights in terms of the legacy to the other texts, one must check Said's book of Orientalism in which it offers the relation between the West and the Orient. In a way or another, a wellunderstood text will be better to be studied from Said's viewpoint in which he highlights the legacies of the East in terms of history and culture that the West benefited from. Also, the Western scholars and media as said before played a vital role in showing the Orient and that is why until now still exists a misunderstanding of the Orient in the eyes of Western culture as a result of the Western's texts.

In an article entitled "Edward Said: the Postcolonial Theory and the Literature and Decolonization" published in a European Scientific Journal, there is a mention of an article written by Edward Said himself: "Islam through Western Eyes” In Said's paper, he sheds light on the false image of the Islam that has been created by the West in their media and writings. Also, the West sees the image of the Islam as a return back in the history. Said emphasizes that there has been a mistake created by the previous Orientalists which is still repeated now in hasty generalization of classifying all Muslims into good or bad (Said, 4). Said's discussion on the conception of the Orient cannot be separated from the issue of Islam. Indeed, Islam is a "lasting trauma" (Said, 59) for the West and it is also associated with barbarism and decadence.

One cannot deny the fact that Said was smart in creating a well chronological order of his books, one can find kind of continuity in his works. After seeing Orientalism and how he portrays the dualism or the binary opposition between the Orient and the Occidental. Indeed Said, mentions that he analyses multiple Orient including French, German, and the British. So Said in his book 'The Question of Palestine ‘ 1979 which one will explore it in next few lines was a case study for Orientalism . 
Said in 'The Question of Palestine' 1979 starts narrating . In a sense, he wants to give the Palestinians voice, so this book could be a voice and face at the same time. In the introduction, he includes allegations said about the Orient and precisely about the Palestinians that they are 'terrorists'. Thus, Said's comment on linking Palestinians with terrorist from his book:

'Yet I suppose that to many of my readers the Palestinian problem immediately calls forth idea of "terrorism, " and it is partly because of this invidious association that I do not spend much time on terrorism in this book. To have done so would have been to argue defensively, either by saying that such as it has been our "terrorism" is justified, or by taking the position that there is no such thing as Palestinian terrorism as such' (xxxvi).

Additionally, in chapter one 'The Question of Palestine' he mentions the modern era there has been a line drawn between Greece and Turkey was named the Orient (Said, 3). Said sees this a 'designation made in Europe, 'the Orient' for many centuries represented a special mentality, as the phase 'the Oriental mind, 'and also a set of special cultural, political and even racial characteristics '(Said, 3). What Said believe here is that his poststructuralist view of binary opposition between the East and the West. He continues by saying that the Orient represented as indiscriminate for Europe, however, it is not attached with difference it is linked with vast spaces, colored people, the romance, exotic locals, and lastly the marvels of the East (Said, 3). It is obvious that the Occidental studied the Orient in order to dehumanize them in a wording, the Occident just made a generalization for the Orient's idea which means after the line that the Europe drawn they start calling what is after the line the Orient and sees it in special angle as Said mentions indiscriminate.

Before Said begins talking about the Palestinians, he locates the Middle East by saying that 'the Middle East, survives today as a region of the Orient connoting infinite complexities, problems, conflicts' (Said, 4). Nowadays it is clearly what is happening in the 
Middle East including Palestine, Iraq, Syria and Yemen. How that countries became after civil wars and corruption.

The sense of dehumanization of the Middle East existed for ages and when it refers to Palestine terrorism is linked to Palestinians. Said in here says: 'No Foreign affairs symposium scholarly book, or moral attitude taken is complete without some reference to Palestinian (sometimes also known as 'Arabs') terrorism. Not only this, the Palestinians has been specified and linked with characteristics of refugees (Said, 4). Said affirms in the duality which has been created he says: 'Weizmann's candor is instructive. His principal rhetorical device is to identify himself with Balfour as a European who knows the difference between the Oriental and the Occidental mind' (Said, 28).

Therefore Said arguing that this is dehumanization for sake of colonialization he says: 'With regard to the Arabs that Wilson describes here, Jewish exclusiveness does not seem like much of an evil. In his brief portrait of them, the Arabs are seen as totally disgusting and unattractive; the reason for their poverty seems less important than its appearance, although the facts about Arabs in Israel would not have been hard for Wilson to get hold of. As for his remarks about the Arab and his sense of family, these can only be understood as one would understand remarks about "Orientals" not having the same regard for human life that "we" do. In other words, Arabs don't care for children, they don't feel love or anger, and they are simply quick-breeding animals' (35).

The issue that Said addressed later, he histories the of the Arab's identity He says: 'Inside Israel the Arab has traditionally been regarded as somebody to be prevented from ever acquiring a national consciousness. The curriculum is changed suddenly, Arab schools and school facilities are in noticeably bad shape, and in all possible ways the Arab is taught to live with his inferiority and his abject dependence on the state' (127). 
Said generalizes the whole picture of the Arabs and not looking for details as some people do or did. He narrates by saying: 'Old, respected demarcations, observed pieties, stable communities, have receded in importance as a result. And I think it is true that there is a tighter, less generous nationalism--one might even call it factionalism-in the Arab air' (Said, 182).

In an article untitled 'The Idea of Palestine in the West 'published by Middle East Research and Information Project. Inc. Ongoing more specific to the relation of Zionism with Palestinians. Said's personifications of the Zionism as he said: Zionism, like its Western ideological parents, drew on this collective representation of the Arabs and Islam ( Said, 5). In this sense Said shows that for them the Arabs and Islam are merely representation of stupidity. What keeps the Zionists superior is that; they believed in themselves as they belong to Eastern partitions in addition to that to explain the West who are the Oriental, Arabs (Said, $6)$.

As always our concern in this paper to see how the West identifies the East. What the Westerner generally sees in the Middle East derives from the scope of Zionism as if Zionists are part of the West. As Said mentions later: 'Israel is the norm, Israelis are the presence, their ideas and institutions the authentically native ones: Arabs are a nuisance, Palestinians a quasi-mythical reality' (Said, 8). For Said, the West and Zionist's relation with each other was not a hegemonic relation but it is rather 'acquiescence'. As a result, the Arab had become a non-person due to the fact the Zionist had become the only person in Palestine because of the Arab's negative personality inferior and decadent which lead them as intensified (Said, 8).

Said's book of Covering Islam was the first in the World who studies the western media of depicted the Muslims where he examines how the media 'preferred' to misinterpret Islam and Muslims. Said's Orientalism 1978 offers such methodological theory or a tool to 
deconstruct the Western's belief. And now, he is using this approach to see how the press in the West treated the Islam (Nuruallah, 1026).

From the beginning of this book Said's argument is that there is consensus about Islam in which everything happened is related to Islam. Therefore, Islam becomes as scapegoat for events people don't know whatever economical or political (Said, IV). One should not take this idea for granted however, one can see that there is a problem of duality inherent in the Western thought. Said problemtizes their perception or thought and he wants to reconstruct it besides enlightening the idea that the Western Media is thin plus, superficial there is no depth.

Scholars have been forming ideas and thoughts about the Islam and East in general especially from the United States. Said argues that there is an ideology to let the American believe that the World media about Islam is dangerous. Said saw this from the intellectual who generalize for the Islam in which he says: 'he says that this understanding influences the way of thinking of politics and many other from cultural sectors that help disseminate opinions' (Gomes, 75).

Talking about the pattern as Said believes in the affiliation between politics and language and the Islam is attributed for sure. In drawing link between the Islam and politics, Said's view is that what do say the academic experts in Islam is not far from politics (Said, IVII). From this idea one gets that it is all about politic.

It was very relevant to mention that Said has been influenced by the Emerson's idea of 'Self-reliance'. He says that 'Their image of the world, and of themselves, are given to them by crowds of witnesses they have never met and shall never met. Yet for every man these images- provided by strangers and dead man-are the very basis of his life as a human being' (Said, 46). 
Again on putting light in Emerson's believe of nonconformity. Said says that the consciousness of men do not determine their material existence; nor does their material existence determine their consciousness'. By this he mean go out of the group (Said, 46).

Said's perception is that there is always generalization on the media about Islam. In a way to show us the stereotyping is happening he affirms:

'American media coverage of foreign countries not only creates itself but also intensifies interests "we" already have there. Media points of view stress certain things for an American, others for an Italian or Russian. All of this converges around a common center, or consensus, which all the media organizations almost certainly feel themselves to be clarifying, crystallizing, forming' (52).

In here, Said is saying that there is no neutrality and shedding light on the danger of the media. So the media distorted the picture of Islam as Said says: 'To speak of 'Islam' in the West today is to mean a lot of the unpleasant things I have been mentioning' (Said, 10). Whenever Islam in such subject is it linked with bad image as the 'Other'. This has been done by the Western media's imaginative coverage.

In Said's thesis in this book, Covering Islam is that 'the canonical orthodox coverage of Islam that we find in the academy, in the government, and all the media is interrelated and has been more diffused, has seemed more persuasive and influential, in the West than any other coverage of interpretation'. In relation to the argument of this paper, the Other from Said's point of view he sees that politics had great role in portraying Islam as it now viewed in the West. For them Islam means the Other, terrorists and barbarism. Said calls for the West's success of coverage and he related it to politics in a sense Capitalism is the problem (Said, 169).

In an article untitled 'The coverage of Islam-marginalized and moralizing narratives', the main argument on this article that claims a theory of how the press depicts 
Islam in media nowadays (Gomes, 71). The media influences the contemporary international audiences. It has been mentioned also how the Muslims represented as the Other, the different who pertains to a distant and uncivilized culture (Gomes, 72).

Under the coverage of media, Gomes argues that during the US intervention in Iraq 2003, the idea is that they created an image of culture and differences. Therefore, this super power depicts the Muslims as subaltern, inferior, archaic, and primitive (Gomes, 73).

Said says that: 'The majority of the Islamic world is crumbling with social divisions, frustrated by its material inferiority in relation to the West embittered at Western cultural influences' (Gomes, 77). It is very clear always to make the Muslims as inferior with keeping them frustrated by the Western culture. There is a purpose behind this coverage of media which is putting Muslims in position as a people who are not serious in their jobs because of the time that Muslims offer for their religion (Gomes, 81).

In an article, Portrayal of Muslims in the media: '24' and the Othering process which asserts in the beginning that Van Der Veer 2004 indicates that being a Muslim and being an Arab only by their names it has is related to dispersed groups who commit suicide by bombing in the name of Islam. Indeed, the media has created imaginative ideas about the Islam in which any act of violence is linked to Muslims (Nuruallah, 1021).

Historically speaking the negative thought that has been attached to Muslims precisely in media starts after the World War II. One can see this where the media depicts Muslims during the 9/11, whereby Islam has been linked with terrorist.

\section{Conclusion}

To conclude one would say that Islam has always been seen as for barbarous 'other'. Said in his books was aware of creating such well-ordered chronological thoughts. By starting from Orientalism 1978 in which he focuses on creating the binary opposition 
between the East and the West by arguing that the relation is relation of Power, domination and hegemony. In his book, The Question of Palestine 1979, Said offers a case study from Orientalism in which he narrates the history of Palestine and Zionism by referring that Zionism was successful in brining Jews to Palestine and constructing part of history. Also he conveys the readers by saying that the Palestinian experience is concrete part of history. Said's Other in this book was the reference of Palestinians as Terrorists. Going further to Covering Islam 1981 in which he focuses in his study on the West's effect on the image of the Islam and how the media has been covered by Islam. From the first book, we can see how the East is distorted through Western discourse, which was the relation of hegemony. In the second book by history, he localizes the complex hegemonic problem of the Palestinians the 'Other 'with Zionism. Lastly, the third book Covers Islam which provides how the West has racial fundamentalists scholars has always an idea to mistreat or misinterpret the Muslims as the 'Other'. 


\section{Works Cited}

Ashcroft, Bill, et al. The Empire Writes Back: Theory and Practice in Post-Colonial Literatures. W. Ross MacDonald School Resource Services, 1989.

Lutfi, Hamadi, "Edward Said: the postcolonial theory and the literature and decolonization", European Scientific Journal, n. p, June 2014.

Reilly, James A. "Western Media and Islam: Covering Islam: How the Media and the Experts Determine How We See the Rest of the World. Edward W. Said.” Journal of Palestine Studies, Vol. 11, No. 1, 1981, pp. 161-164., doi:10.1525/jps.1981.11.1.00p0354s.

Said, Edward W. Orientalism. Penguin, 2003.

Said, Edward W. The Question of Palestine. Vintage, 1979.

Said, Edward, W.,' The Idea of Palestine in the West'”. Middle East Research and Information Project. Inc, No 70, 1978, pp. 3-11.

Said, Edward W. Covering Islam. Vintage, 1997.

Abu Sadat, Nuruallah. "Portrayal of Muslims in the media: "24" and the 'Othering' process." International Journal of Human Sciences, Vol. 7, No. 1, 2010, pp. 1021 -1046.

Ingrid, Gomes. "The coverage of Islam- marginalized and moralizing narratives." Intercom, Rev. Bras. Ciênc. Comun, Vol 37, No 1, 2014, pp. 71-89. 